\title{
PERBEDAAN PENGARUH LATIHAN ONE HAND SET SHOOT DAN TWO HAND SET SHOOT TERHADAP TEMBAKAN BEBAS (FREE THROW) DALAM PERMAINAN BOLA BASKET PADA ATLET BALKA CLUB TAHUN 2020
}

\author{
Maulana Iqbal ${ }^{a}$, Agustanico Dwi Muryadi, S.Pd, M.Pd ${ }^{b}$, Karlina Dwijayanti S.Pd, M.Orc \\ abcPhysical Education, Universitas Tunas Pembangunan Surakarta, Surakarta, Indonesia. \\ email:amaulanaiqbal@gmail.com
}

\begin{tabular}{l}
\hline I N F O A R T I K E L \\
\hline Sejarah artikel: \\
Menerima 1Juli 2021 \\
Revisi 21 Juli 2021 \\
Diterima 22 \\
Online 30 Juli 2021
\end{tabular}

Kata kunci:

Bola Basket, One

Hand,Two Hand,Free

Trow

\section{Keywords:}

Basket ball,One Hand,

Two Hand, Free Throw

Style APA dalam mensitasi artikel ini: [Heading sitasi] Maulana Iqbal 2020.

Perbandingan Latihan One Hand Set Shoot dan Two Hand Set Shoot Terhadap Tembakan Bebas (Free Throw) dalam Permainan Bola Basket pada Atlet Balka Club Tahun 2020 Jurnal Ilmiah Penjas ( Volume 7. No 2) (57-71)

\begin{abstract}
ABSTRAK
Tujuan dari penelitian ini adalah : (1) Mengetahui pengaruh latihan one hand set shoot terhadap tembakan bebas (free throw) dalam permainan bola basket. (2) Mengetahui pengaruh latihan two hand set shoot terhadap tembakan bebas (free throw) dalam permainan bola basket. (3) Mengetahui perbedaan pengaruh antara one hand set shoot dan latihan two hand set shoot terhadap tembakan bebas (free throw) dalam permainan bola basket. Metode penelitian yang digunakan adalah metode eksperimen. Subjek dalam penelitian ini adalah atlet peserta Balka Club sejumlah 30 peserta di Desa Purwodadi Kecamatan Purwodadi Kabupaten Grobogan tahun 2020. Teknik pengumpulan data untuk memperoleh data yang diperlukan dalam penelitian ini menggunakan tes tembakan one hand dan two hand terhadapat tembakan bebas (free throw). Berdasarkan hasil analisis data: Ada pengaruh yang signifikan latihan tembakan one hand terhadap tembakan bebas (free thow) bola basket pada atlet Balka Club 2020 (1). Ada pengaruh yang signifikan latihan tembakan two hand terhadap tembakan bebas (free throw) bola basket pada atlet Balka Club 2020 (2). Ada perbedaan pengaruh yang signifikan antara latihan tembakan one hand dan two hand terhadap tembakan bebas (free thow) bola basket pada atlet Balka Club 2020. Dari perhitungan yang telah dilakukan diperoleh nilai $t$ sebesar 0,879 , ternyata lebih kecilt_(tabel $5 \%$ )yaitu 2,131. Latihan tembakan two hand lebih baik pengaruhnya terhadap kemampuan tembakan bebas (free throw) bola basket pada atlet Balka Club 2020. Peningkatan kemampuan latihan tembakan bebas (free throw) kelompok 2 (kelompok yang mendapat perlakuan latihan tembakan two hand) adalah sebesar 92\%> kelompok 1 (kelompok yang mendapat perlakuan latihan tembakan one hand ) yaitu sebesar $74 \%$ (3).
\end{abstract}

\section{ABSTRACT}

The aims of this study were: (1) To determine the effect of one hand set shoot practice on free throws in basketball games. (2) Knowledge of the effect of the two hand set shoot exercise on free throws in basketball games. (3) Knowing the difference in the effect between one hand set shoot and two hand set shoot exercises on free throws in basketball games. The research method used is the experimental method. The subjects in this study were Balka Club athletes number 30 participants in Purwodadi Village, Purwodadi District, Grobogan Regency in 2020. The collection technique to obtain the data needed in this study used a one-handed and two-handed shot test against free throws. results based on data analysis: There is a significant effect of one-handed shooting practice on basketball free throws in Balka Club 2020 athletes (1). There is a significant effect of two-handed shooting practice on basketball free throws for Balka Club 2020 athletes (2). There is a significant difference in the effect of one-handed and two-handed shooting practice on basketball free shots for 
Balka Club 2020 athletes. From the calculations that have been made, the t-value is 0.879 , it is smaller (table 5\%) which is 2.131. Two-handed shooting training has a better effect on basketball free throw skills for Balka Club 2020 athletes. The increase in free throw practice skills in group 2 (the group receiving two-handed training) is $92 \%>$ group 1 (the group that received the one-handed shot practice treatment) was $74 \%(3)$.

\section{Pendahuluan}

Permainan bola basket merupakan permainan yang dinamis dan atraktif terutama berkenaan dengan cara memainkan bola baik saat dribbling, passing maupun shooting. Permainan bola basket semakin menarik ketika para pemain memperagakan dengan berbagai atraksi antara lain three-point shoot, lay-up shoot dan slam-dunk. Menembak adalah unsur teknik shooting yang menentukan dalam kemenangan dalam pertandingan, sebab kemenangan ditentukan oleh banyaknya bola yang masuk ke keranjang. Setiap regu yang menguasai bola selalu mencari kesempatan untuk dapat menembak. Setiap serangan selalu berusaha dapat berakhir dengan tembakan. Oleh kerena itu unsur menembak ini merupakan teknik dasar yang harus dipelajari dengan baik dan benar serta ditingkatkan keterampilannya dengan latihan. Menurut Danny Kosasih (2008: 2), bola basket adalah permainan yang menggunakan kecepatan (kaki dan tangan) dalam waktu yang tepat. Hal tersubut harus dilatihkan saat mengembangkan serta melatih skill individu pemain, fisik, emosi dan team balance, baik dalam posisi defense maupun offense. Pada pertandingan bola basket sering kita lihat para pemain basket menggunakan berbagai teknik shooting untuk menambah poin. Keakuratan atau ketepatan hasil shooting kearah keranjang tergantung dari pemain itu sendiri dan keadaan pertahanan lawan.

Menurut Gusti Ari Sandika (2013: 2) “Tembakan bebas adalah tembakan yang dihadiahkan pada seorang pemain untuk mendapatkan angka, sebagai akibat diganggunya dengan kasar oleh pemain lawan dalam usaha tembakan lapangan". Tembakan bebas dilaksanakan dibelakang garis tembakan bebas tanpa rintangan. Teknik One hand shoot dan two hand shoot dalam suatu pertandingan masih merupakan fenomena, karena banyak anggapan berbeda yang muncul. Satu pihak 
menyatakan one hand shoot lebih efektif dan pihak yang lain menyatakan two hand shoot lebih efektif pada tembakan bebas.

Berdasarkan jenisnya atau cara melakukan shooting bola basket dapat dilakukan dengan satu tangan atau dua tangan. Sedangkan di dalam pelaksanaannya dapat dilakukan dari depan dada, dari atas kepala, dengan melompat. Hal ini bergantung dari kebiasaan pemain dalam melakukan shooting bola basket.

Pada umumnya shooting sangat digemari siswa sekolah . Namun banyak mengalami kendala, sehingga seringkali tembakannya gagal. Tidak semua atlet Balka Club Purwodadi mampu melakukan shooting bola basket dengan baik. Ketidakmampuan siswa melakukan shooting bola basket tersebut disebabkan oleh beberapa faktor, misalnya kekuatan yang belum memadai bola yang terlalu berat atau ring yang terlalu tinggi. Kendala atau masalah yang dihadapi siswa dalam proses belajar shooting, pelatih harus menganalisa dan mencari solusi yang tepat agar tujuan pembelajaran dapat tercapai dengan baik. Jika dalam latihan shooting ada beberapa siswa belum memiliki kekuatan yang memadai (terlalu berat), maka perlu langkah yang tepat disesuaikan kondisi siswa.

Sebuah tembakan memerlukan teknik menembak yang baik supaya saat melakukanya memperoleh hasil yang bagus. Salah satunya adalah teknik tembakan yang kurang baik. Apakah sudah semua atlet bola basket melakukan teknik tembakan dengan baik dan benar? Masih banyak atlet melakukan tembakan dengan teknik gerakan yang tidak benar, untuk membentuk tembakan yang baik dan benar dibutuhkan latihan shooting dengan teknik dasar dan yang diberikan saat seorang atlet masih dini atau saat muda. Melakukan tembakan dalam permainan bola basket memerlukan gerakan kompleks meliputi gerakan tungkai, tubuh, dan lengan. Jauh dekatnya tembakan dipengaruhi oleh posisi pemain dari keranjang dan jangkauan pemain, untuk melakukan tembakan diperlukan adanya koordinasi dari bagian ujung bawah tubuh sampai ujung jari yaitu antara kaki, punggung, bahu, siku, lengan, pergelangan tangan, dan jari tangan. Oleh karena itu unsur menembak ini merupakan 
teknik dasar yang harus dipelajari dengan baik dan benar beserta ditingkatkan keterampilanya dengan latihan.

Teknik free throw dalam bola basket mempunyai peran yang sangat penting, karena dalam melakukan free throw bukan hanya dibutuhkan teknik yang baik tetapi juga ketenangan dari penembak untuk mendapatkan hasil dari tembakan free throw. Meskipun dalam perolehan angka free throw hanya diberi nilai satu angka setiap bola masuk, tetapi bagi penembak yang berhasil membuat angka dari free throw akan semakin membuat percaya diri dan mampu mengulanginya lagi. Bahkan dalam suatu pertandingan yang ketat perolehan angkanya, satu tembakan free throw yang masuk di akhir-akhir laga dapat memenangkan salah satu tim dalam pertandingan. Free throw dilakukan oleh pemain sesuai dengan kemampuannya, ada yang melakukan dengan teknik satu tangan dan teknik dua tangan, ada juga yang melempar dengan menggunakan tangan kanan atau tangan kiri.

Tembakan bebas adalah tembakan yang di berikan kepada seorang pemain lawan yang di sebabkanlawan melakukan pelanggaran, Oleh karena itu peneliti tertarik untuk melakukanpenelitian ini. Atas dasar hal ini maka masalah utama yang harus dipecahkan adalah memberi latihan teknik shooting yang lebih efesien dan efektif dengan konsep BEEF. BEEF ialah sebuah konsep shooting yang memudahkan atlet untuk memahami dan menguasai teknik tembakan dengan baik dan benar. Keuntungan melakukan tembakan dengan konsep BEEF adalah efektif dan efesien mudah di mengerti. Cukup banyak manfaat latihan shooting dengan konsep BEEF. Apakah para pelatih sudah banyak memanfaatkan latihan shooting dengan konsep BEEF? masih diragukan. Latihan ini seharusnya diberikan kepada calon atlet yang baik sejak dini untuk membuat atlet berprestasi tinggi.

Berdasarkan observasi awal pada hari senin tanggal 8 Juni 2020 ditemukan bahwa ada kekurangan teknik pelatihan dan hasil shooting free throw kurang maksimal. Melihat kemampuan atlet tim Balka dalam melakukan shooting berbedabeda. Selain itu ketepatan saat melakukan tembakan ke ring masih kurang konsisten 
dan metode latihan tentang shooting free throw monoton atlet mudah merasa bosan, artinya dalam sebuah pertandingan latihan saat melakukan tembakan kadang masuk, kadang tidak. Hal ini membuat peneliti tertarik mengambil penelitian yang bertujuan memperbaiki shooting free throw.

Berdasarkan uraian di atas, bahwa dalam melakukan shooting free throw pada permainan bola basket diperlukan juga kemampuan gerakan yang efektif dan efisien dalam suatu rangkaian gerak dan mengetahui faktor yang mana mempegaruhi keberhasilan tembakan untuk meningkatkan hasil ketepatan shoothing free throw yang efektif dan efesien, maka perlu diadakan penelitian tentang "perbandingan latihan one hand set shoot dan two hand set shoot terhadap tembakan bebas (free throw) dalam permainan bola basket pada siswa Balka Club tahun 2020".

\section{Metode}

Metode yang digunakan dalam penelitian ini adalah penelitian kuantitatif dengan menggunakan metode eksperimen. Subyek dalam penelitian ini adalah peserta Balka Club sejumlah 30 peserta di Desa Purwodadi Kecamatan Purwodadi Kabupaten Grobogan tahun 2020. Teknik pengumpulan data untuk memperoleh data yang diperlukan dalam penelitian ini menggunakan tes tembakan one hand dan two hand terhadapat tembakan bebas (free throw). Dalam penelitian ini peserta Balka Club melaksanakan latihan tembakan one hand dan tembakan two hand terhadap tembakan bebas (free throw) bola basket.

\section{Hasil dan Pembahasan}

\section{A. Deskripsi Data}

Data yang dikumpulkan terdiri dari data tes awal, kemudian dikelompokkan menjadi dua kelompok yaitu kelompok 1 dan kelompok 2, serta data tes akhir pada masing-masing kelompok. Data tersebut kemudian dianalisis dengan statistik, seperti terlihat pada tabel 1 sebagai berikut :

Tabel 1. Deskripsi Data Hasil Tes Tembakan One Hand dan Two Hand Terhadap Hasil Tembakan Bebas (Free Throw) Bola Basket pada Kelompok 1 dan 2 


\begin{tabular}{|c|c|c|c|}
\hline Kelompok & Tes & Mean & SD \\
\hline \multirow[b]{2}{*}{ Kelompok 1} & Awal & 50,200 & 10,465 \\
\hline & Akhir & 55,814 & 1,224 \\
\hline \multirow[b]{2}{*}{ Kelompok 2} & Awal & 50,200 & 10,465 \\
\hline & Akhir & 57,184 & 1,224 \\
\hline \multicolumn{4}{|c|}{ Penjelasan tiap kelompok } \\
\hline K1 & \multicolumn{3}{|c|}{$\begin{array}{l}\text { Berdasarkan tabel kelompok } 1 \text { di atas latihan menggunakan } \\
\text { tembakan one hand terhadap tembakan bebas (free throw) bola } \\
\text { basket pada tes awal dan tes akhir ditinjau dari mean dan SD }\end{array}$} \\
\hline $\mathrm{K} 2$ & \multicolumn{3}{|c|}{$\begin{array}{l}\text { Berdasarkan tabel kelompok } 2 \mathrm{di} \text { atas latihan menggunakan } \\
\text { tembakan two hand terhadap tembakan bebas (free throw) bola } \\
\text { basket pada tes awal dan tes akhir ditinjau dari mean dan SD }\end{array}$} \\
\hline
\end{tabular}

\section{B. Pengujian Prasyarat Analisis}

\section{Uji Normalitas}

Hasil uji normalitas data tes awal pada kelompok 1 dan kelompok 2 adalah sebagai berikut :

Tabel2. Rangkuman Hasil Uji Normalitas Data

\begin{tabular}{|c|c|c|c|c|c|}
\hline Kelompok & $\mathrm{N}$ & $\mathrm{M}$ & $\mathrm{SD}$ & $\mathrm{L}_{\mathbf{o}}$ & $\mathrm{L}_{\text {tabel }}$ \\
\hline $\mathrm{K} 1$ & 15 & 50,200 & 10,465 & 0,119 & \multirow{2}{*}{0,220} \\
\hline $\mathrm{K} 2$ & 15 & 50,200 & 10,465 & 0,119 & \\
\hline
\end{tabular}

Dari uji normalitas yang dilakukan pada KI diperoleh data Lo =0,119. Dimana nilai tersebut lebih kecil dari nilai batasnya yaitu 0,220. Dengan demikian dapat 
disimpulkan data pada K1 termasuk distribusi normal. Sedangkan dari data hasil uji normalitas yang dilakukan pada K2 diperoleh nilai Lo = 0,119 yang ternyata lebih kecil dari angka batas penolakan hipotesa Nol yaitu 0,220. Dengan demikian dapat disimpuikan bahwa data pada K2 termasuk distribusi normal.

\section{Uji Homogenitas}

Hasil uji homogenitas antara kelompok 1 dan kelompok 2 adalah sebagai berikut :

Tabel 3. Rangkuman Hasil Uji Homogenitas Data

\begin{tabular}{|c|c|c|c|c|}
\hline Kelompok & N & SD & Fo & Ft5\% \\
\hline Kelompok 1 & 15 & 10,46 & \multirow{2}{*}{0,00} & 2,18 \\
\hline Kelompok 2 & 15 & 10,46 & & \\
\hline
\end{tabular}

Dari uji homogenitas diperoleh nilai $\mathrm{F}=0,00$, sedangkan $\mathrm{db}=14$, angka $\mathrm{F}$ tabel $5 \%=2,18$ yang ternyata bahwa nila $\mathrm{Fo}=0,00$ lebih kecil dari $\mathrm{F}$ tabel $5 \%=2,18$. Sehingga dapat disimpulkan bahwa kelompok 1 dan kelompok 2 memiliki varians yang homogen.

\section{Hasil Analisis Data}

\section{Uji Perbedaan Sebelum Diberi Perlakuan}

Sebelum diperlakuan kelompok yang dibentuk dalam penelitian di uji perbedaannya terlebih dahulu. Hal ini dengan maksud untuk mengetahui ketepatan anggota pada kedua kelompok tersebut. Sebelum diberi perlakuan berangkat dari keadaan yang sama atau tidak. Hasil uji perbedaan tembakan one hand dan tembakan two hand terhadap hasil tembakan bebas (free throw) bola basket antara kelompok 1 dan kelompok 2 dalam bentuk tabel sebagai berikut :

Tabel 4. Rangkuman Hasil Uji Perbedan Tes Awal pada Kelompok 1 dan 2 


\begin{tabular}{|c|c|c|c|c|}
\hline Kelompok & $\mathrm{N}$ & $\mathrm{M}$ & $\mathrm{t}_{\text {hitung }}$ & $\mathrm{t}_{\text {tabel 5\% }}$ \\
\hline Kelompok 1 & 15 & 50,200 & 0,000 & 2,131 \\
\hline Kelompok 2 & 15 & 50,200 & & \\
\hline
\end{tabular}

Dari uji t yang dilakukan dapat disimpulkan bahwa dengan $\mathrm{db}=\mathrm{N}-1=15-1=14$ dan taraf signifikansi 5\%, nilai t dalam tabel $=2,131$. sedangkan nilai t yang diperoleh sebesar 0,000. ternyata lebih kecil dari t tabel 5\%. Dengan demikian hipotesa nol diterima, yang berarti bahwa sebelum diberi perlakuan tidak ada perbedaan yang signifikan antara kelompok 1 dan kelompok 2.

\section{Uji Perbedaan Sesudah Diberi Perlakuan}

Setelah diberi perlakuan, yaitu kelompok 1 diberi perlakuan latihan tembakan one hand dan kelompok 2 mendapat perlakuan latihan tembakan two hand, kemudian dilakukan uji perbedaan.

1) Hasil Tes Awal dan Tes Akhir Tembakan Bebas (Free Throw) Bola Basket Pada Kelompok 1

Tabel.5 Rangkuman Hasil Uji Perbedaan Tes Awal dan Akhir Tembakan One Hand Kelompok 1

\begin{tabular}{|l|l|l|c|c|}
\hline Tes & $\mathrm{N}$ & $\mathrm{M}$ & $\mathrm{t}_{\text {hitung }}$ & $\mathrm{t}_{\text {tabel }}$ \\
\hline K1 Awal & 15 & 50,000 & \multirow{2}{*}{0,877} & 2,131 \\
\hline K1 Akhir & 15 & 55,814 & & \\
\hline
\end{tabular}

Dari hasil tersebut dapat disimpulkan bahwa dengn $\mathrm{db}=\mathrm{N}-1=15-1=14$ dan taraf signifikasi 5\% nilai t dalam tabel $=2,131$. Sedangkan nilai t yang diperoleh sebesar 0,877. Ternyata lebih besar dari t tabel 5\%. Dengan demikian hipotesis nol ditolak, 
yang berarti bahwa terdapat pengaruh yang signfikansi antara hasil tes awal dan hasil tes akhir pada kelompok 1.

\section{2) Hasil Tes Awal dan Tes Akhir Tembakan Bebas (Free Throw) Bola Basket Pada}

\section{Kelompok 2}

Hasil uji perbedaan tes awal dan tes akhir tembakan two hand kelompok 2 disajikan dalam bentuk tabel sebagai berikut :

Tabel 6. Rangkuman Hasil Uji Perbedaan Tes Awal dan Tes Akhir Tembakan Two Hand pada Kelompok 2

\begin{tabular}{|l|l|l|c|c|}
\hline Tes & $\mathrm{N}$ & $\mathrm{M}$ & $\mathrm{t}_{\text {hitung }}$ & $\mathrm{t}_{\text {tabel } 5 \%}$ \\
\hline K2 Awal & 15 & 50,000 & 0,949 & 2,131 \\
\hline K2 Akhir & 15 & 57,184 & & \\
\hline
\end{tabular}

Dari uji yang dilakukan dapat disimpulkan bahwa dengan $\mathrm{db}=\mathrm{N}-1=15-1=$ 14 dan taraf signifikansi $5 \%$ nilai $\mathrm{t}$ dalam tabel $=2,131$. Sedangkan nilai $\mathrm{t}$ yang diperoleh sebesar 0,949 ternyata lebih besar dari t tabel 5\%. Dengan demikian hipotesis nol ditolak, yang berarti terdapat pengaruh yang signifikansi antara hasil tes awal dan hasil tes akhir pada kelompok 2.

\section{3) Hasil Uji Perbedaan Tes Akhir Tembakan Bebas (Free Throw) Bola Basket Pada}

\section{Kelompok 1 Dan Kelompok 2}

Hasil uji perbedaan hasil tes akhir tembakan bebas (free throw) pada kelompok 1 dan kelompok 2 disajikan dalam bentuk tabel sebagai berikut :

Tabel.7 Rangkuman Hasil Uji Perbedaan Tes Akhir Antara Kelompok 1 dan

Kelompok 2

\begin{tabular}{|l|l|l|c|c|}
\hline Tes & $\mathrm{N}$ & $\mathrm{M}$ & $\mathrm{t}_{\text {hitung }}$ & $\mathrm{t}_{\text {tabel } 5 \%}$ \\
\hline K1 & 15 & 55,814 & \multirow{2}{*}{0,879} & 2,131 \\
\hline K2 & 15 & 57,184 & & \\
\hline
\end{tabular}


Dari hasil tersebut dapat disimpulkan bahwa dengan $\mathrm{db}=\mathrm{N}-1=15-1=14$ dan taraf signifikansi 5\% nilai t dalam tabel $=2,131$. Sedangkan nilai t yang diperoleh sebesar 0,879 ternyata lebih besar dari $t$ tabel 5\%. Dengan demikian hipotesa nol ditolak, yang artinya setelah diberi perlakuan terdapat perbedaan pengaruh yang signifikan antara hasil tes akhir pada kelomok 1 dan kelompok 2. Adapun nilai perbedaan peningkatan tembakan free throw bola basket dalam persen pada kelompok 1 dan kelompok 2 disajikan dalam bentuk tabel sebagai berikut :

Tabel 8. Rangkuman Hasil Perhitungan Nilai Perbedaan Peningkatan Tembakan Bebas (Free Throw) dalam Persen Kelompok 1 dan Kelompok 2

\begin{tabular}{|c|c|c|c|c|c|}
\hline Kel & $\mathrm{N}$ & $\begin{array}{c}\text { Mean } \\
\text { Pretest }\end{array}$ & $\begin{array}{c}\text { Mean } \\
\text { Postest }\end{array}$ & $\begin{array}{c}\text { Mean } \\
\text { Different }\end{array}$ & $\begin{array}{c}\text { Persentase } \\
\text { Peningkatan }\end{array}$ \\
\hline K1 & 15 & 50,000 & 55,814 & 5,614 & $74 \%$ \\
\hline K2 & 15 & 50,000 & 57,184 & 6,984 & $92 \%$ \\
\hline
\end{tabular}

Dari hasil diatas dapat diketahui bahwa kelompok 1 memiliki peningkatan kemampuan free throw sebesar 21,63\%. kelompok 2 memiliki peningkatan kemampuan free throw sebesar 27,86\%. Dengan demikian dapat disimpulkan bahwa kelompok 2 memiliki peningkatan kemampuan teambakan bebas (free throw) yang lebih tinggi dari pada kelompok 1 .

\section{Pembahasan Hasil Penelitian}

1. Latihan Tembakan One Hand Terhadap Hasil Tembakan Bebas (Free Throw) Bola Basket

Tembakan yang menggunakan satu tangan ini sering kita lihat di restricted area. Kelebihan dari tembakan satu tangan ini adalah upaya on ball defense dari serbuan defender lawan. Satu tangan lainnya memastikan sang pemain punya cukup ruang untuk menembak. Kelompok 1 kelompok (yang mendapat perlakuan tembakan one hand) memiliki nilai persentase peningkatan tembakan bebas (free throw) bola basket 
sebesar 21,63\%. Latihan tembakan one hand dalam penguasaan bola saat melakukan tembakan bebas sulit dicapai secara maksimal, sehingga akan sering terjadi kesalahan teknik tembakan. Penguasaan teknik yang kurang memadai, sehingga tembakan bebas (free throw) yang dilakukan tidak sesuai seperti yang diharapkan.

2. Latihan Tembakan Two Hand Terhadap Hasil Tembakan Bebas (Free Throw) Bola Basket

Kelompok 2 (kelompok yang mendapat perlakuan tembakan two hand) memiliki peningkatan tembakan bebas (free throw) bola basket sebesar 27,86\%. Dengan demikian dapat disimpulkan bahwa kelompok 2 memiliki persentase peningkatan tembakan bebas (free throw) bola basket yang lebih besar dari pada kelompok 1 .

Kelompok 2 ternyata memiliki peningkatan tembakan bebas (free throw) yang lebih besar dari pada kelompok 1 (kelompok yang mendapat perlakuan tembakan one hand). Latihan tembakan two hand ini sangat tepat untuk pemula, karena dengan latihan tembakan two hand, atlet akan memahami dan menguasai teknik teambakan bebas (free throw) normal yang baik. Penguasaan teknik yang benar akan dapat mendukung kemampuan tembakan bebas (free throw) bola basket menjadi lebih baik. Dengan demikian hipotesis yang menyatakan latihan tembakan two hand lebih baik pengaruhnya terhadap kemampuan tembakan bebas (free throw) pada atlet Balka Club 2020, dapat diterima kebenarannya.

3. Perbedaan Latihan Tembakan One Hand dan Two Hand Terhadap Hasil Tembakan Bebas (Free Throw) Bola Basket

Pengaruh suatu latihan adalah bersifat khusus, sehingga perbedaan perlakuan akan menimbulkan pengaruh yang berbeda pula. Dari analisis data yang dilakukan sebelum diberi perlakuan. Diperoleh nilai $\mathrm{t}$ antara tes awal pada kelompok 1 dan kelompok 2 adalah 0,000 sedangkan $t_{\text {tabel } 5 \%}=2,131$. Ternyata $t$ yang diperoleh $<t$ dalam tabel, yang berarti hipotesis nol diterima. Dengan demikian kelompok 1 dan kelompok 2 berangkat dari titik tolak tembakan bebas (free throw) bola basket yang 
sama. Apabila setelah diberi perlakuan terdapat perbedaan, hal ini karena adanya perbeda perlakuan yang diberikan.

Nilai $t$ antara tes awal dan tes akhir pada kelompok $1=0,877$. Sedangkan $t_{\text {tabel } 5 \%}$ $=2,131$. ternyata $\mathrm{t}$ yang diperoleh $>\mathrm{t}$ dalam tabel. Yang berarti hipotesis nol ditolak. Dengan demikian dapat disimpulkan bahwa terdapat perbedaan yang signifikan antara hasil tes awal dan tes akhir pada kelompok 1 . Yang berarti bahwa kelompok 1 memiliki peningkatan tembakan bebas (free throw) yang disebabkan oleh treatment (perlakuan) yang diberikan, yaitu tembakan one hand.

Nilai $t$ antara tes awal dan tes akhir pada kelompok $2=0,949$. Sedangkan $t_{\text {tabel } 5 \%}$ $=$ ternyata $\mathrm{t}$ yang diperoleh $>\mathrm{t}$ dalam tabel, yang berarti hipotesis nol ditolak. Dengan demikian dapat disimpulkan bahwa terdapat perbedaan antara hasil tes awal dan tes akhir pada kelompok 2. Yang berarti kelompok 2 memiliki peningkatan lebih baik terhadap tembakan bebas (free throw) yang disebabkan treatment (perlakuan) yang diberikan, yaitu tembakan two hand.

Dari uji perbedaan yang dilakukan terhadap hasil tes akhir pada kelompok 1 dan kelompok 2, diperoleh nilai t sebesar 0,879 . Sedangkan $\mathrm{t}_{\text {tabel } 5 \%}=2,131$. Ternyata $\mathrm{t}$ yang diperoleh $>\mathrm{t}$ dalam tabel, yang berarti hipotesis nol ditolak. Dengan demikian dapat disimpulkan bahwa setelah diberi perlakuan sesuai jadwal yang telah diprogramkan dalam penelitian, terdapat perbedaan yang signifikan antara hasil tes akhir pada kelompok 1 dan kelompok 2. Karena sebelum diberi perlakuan kedua kelompok berangkat dari titik tolak yang sama, maka perbedaan tersebut disebabkan perbedaan pengaruh dari perlakuan yang diberikan.

Karakteristik latihan-latihan dapat menghasilkan pengaruh yang berbeda. Perlakuan yang diberikan selama latihan merupakan stimulus yang akan memperoleh respon dari pelaku. Dalam penelitian ini kelompok 1 dan kelompok 2 diberi perlakuan (treatment) yang berbeda. Perbedaan yang diberikan selama latihan akan mendapat respon yang berbeda pula dari subyek penelitian. Perbedaan perlakuan yang diberikan selama latihan akan menimbulkan pengaruh yang berbeda pula terhadap peningkatan 
tembakan bebas (free throw) bola basket. Dengan demikian hipotesis yang menyatakan ada perbedaan latihan tembakan one hand set shoot dan two hand set shoot terhadap hasil tembakan bebas (free throw) pada atlet Balka Club 2020, dapat diterima kebenarannya.

\section{Simpulan}

Berdasarkan hasil penelitian dan hasil analisis data yang telah dilakukan, ternyata hipotesis yang diajukan dapat diterima, sehingga diperoleh simpulan sebagai berikut :

1. Ada pengaruh yang signifikan latihan tembakan one hand terhadap tembakan bebas (free thow) bola basket pada atlet Balka Club 2020.

2. Ada pengaruh yang signifikan latihan tembakan two hand terhadap tembakan bebas (free throw) bola basket pada atlet Balka Club 2020.

3. Ada perbedaan pengaruh yang signifikan antara latihan tembakan one hand dan two hand terhadap tembakan bebas (free thow) bola basket pada atlet Balka Club 2020. Dari perhitungan yang telah dilakukan diperoleh nilai t sebesar 0,879 , ternyata lebih kecilt tabel $5 \%$ yaitu 2,131. Latihan tembakan two hand lebih baik pengaruhnya terhadap kemampuan tembakan bebas (free throw) bola basket pada atlet Balka Club 2020. Peningkatan kemampuan latihan tembakan bebas (free throw) kelompok 2 (kelompok yang mendapat perlakuan latihan tembakan two hand) adalah sebesar 92\%> kelompok 1 (kelompok yang mendapat perlakuan latihan tembakan one hand ) yaitu sebesar $74 \%$.

\section{Ucapan Terimakasih}

Saya sampaikan terimakasih kepada pelatih dan atlet Balka Club yang telah bersedia menjadi sampel dalam penelitian ini, ucapan yang sama juga saya ucapkan kepada pimpinan khususnya bapak Dekan FKIP dan Kaprodi Penjas yang telah mendukung peneitian ini sehingga dapat berjalan dengan baik dan lancar, semoga penelitian ini dapat bermanfaat bagi seluruh masyarakat.

\section{Referensi}

Agung dan Syaifulloh. 2011. Metode Penelitian Keolahragaan. Surakarta: Yuma Presindo. 
Agus Margono. 2010. Permainan Bola Basket. Surakarta: Sebelas Maret University.

Andi Suhendro. 2007. Dasar-Dasar Kepelatihan. Jakarta: Universitas Terbuka.

Kosasih, Danny. 2008. Pengertian Basketball. Semarang : Karangturi Media

Deni Darmawan. 2013. Metode Penelitian Kuantitatif. Bandung: PT Remaja Rosdakarya.

Emral. 2017. Pengantar Teori dan Metodologi Pelatihan Fisik. Depok: Prenada Media.

Gede Eka Budi Darmawan. 2015. Cabang Olahraga Bola Basket. Yogyakarta: Graha Ilmu. 2012. Cabang Olahraga Bola Basket. Yogyakarta: Graha Ilmu.

Gusti Ari Sandika. 2013. Perbandingan Ketepatan One Hand set Shoot dan Two Hand Set Shoot pada Tembakan Bebas dalam Permaian Bola Basket Siswa SMA N 1 Torue: EJTPEHR. Volume 1 Nomor 3. Hal1-14.

Hall Wissel. 1996. Basketball Step to Succes. Jakarta: Raja Grafindo Persada.

Hidayattullah, M. F. (2002).Pembinaan Olahraga Usia Dini. Surakarta: Pusat Penelitiandan Pengembangan Keolahragaan (Puslitbang-OR) Universitas Sebelas MaretSurakarta.

Hasan Suryono. 2014. Metode Analisis Statistik. Yogyakarta: Penerbit Ombak.

http://walpaperhd99.blogspot.com/2015/08/teknik-menembak-shooting-bolabasket.html?m=1 (Diakses pada tanggal 5 agustus 2015 pukul $17.44 \mathrm{wib}$ )

http://sport.10terbaik.com/2012/12/teknik-dasar-bola-basket.html (Diakses pada tanggal 05 desember 2012 pukul $15.38 \mathrm{wib}$ )

http://www.firmanwinardi.com/2020/05/teknik-dasar-shooting-bolabasket.html?m=1 (Diakses pada tanggal 15 mei $202018.54 \mathrm{wib}$ )

I Nyoman Eka Jepri Yasa (2014) Pengaruh Pelatihan Shooting Dengan Menggunakan Satu Tangan Dan Dua Tangan Terhadap Ketepatan Shooting Bola Basket Siswa Ekstrakurikuler Smp Laboratorium Undiksha Tahun 2014: Jurnal Kepelatihan Olahraga. Volume 1 Nomer 2. Hal 1-9.

Kukuh Ciphana Hendra Kusuma. 2019. Pengaruh Tembakan Under The Basket Shoot dan Koordinasi Mata Tangan terhadap Hasil Tembakan pada Siswa Ekstrakurikuler Basket di MAN 1 Semarang. Tesis. Universitas Negeri Semarang. 
Mulyono, B. 2009. Tes dan Pengukuran dalam Pendidikan Jasmani/Olahraga. Surakarta: JPOK FKIP UNS.

Nelson. 1986. Practical Measurements for Evaluation in Physical education. New Delhi: Surjeet Publications, (3rd ed.), Indian reprint.

Nuril. 2007. Permaian Bola Basket. Editor, Alee. -Surakarta: Era Intermedia

Sugiyono. 2006. Metode Penelitian Kuantitatif, Kualitatif dan R \& D. Bandung: Alfabeta. . 2010. Metode Penelitian Kuantitatif, Kualitatif dan R \& D. Bandung: Alfabeta. .2013. Metode Penelitian Kuantitatif, Kualitatif dan R \& D. Bandung: Alfabeta. . 2016. Metode Penelitian Kuantitatif, Kualitatif dan R \& D. Bandung: Alfabeta.

Sudjana. 2002. Metode Statistika. Bandung: Tarsito.

Suharsimi Arikunto. 2010. Prosedur Penelitian.Yogyakarta: Rineka Cipta.

Sukma Aji. 2016. Buku Olahraga Paling Lengkap: Pamulang. Ilmu Cemerlang Group.

UU No 3. 2005. Sistem Keolahragaan Nasional. Jakarta. Humas dan Hukum.

Tudor O. Bompa. 1994. Periodization. York University: Human Kinetics.

Widiastuti. 2015. Tes dan Penguuran Olahraga. Jakarta: PT Raja Grafindo Persada. 